\title{
Port congestion determinants and impacts on logistics and supply chain network of five African ports
}

\section{Ibeawuchi C. Nze, Chinedum Onyemechi}

Federal University of Technology Owerri, PMB 1526, Owerri, Nigeria

Department of Maritime Management Technology

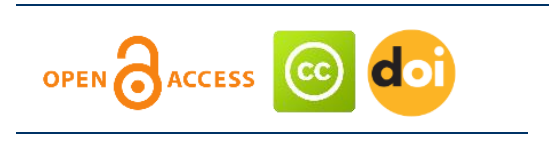

\section{Article history:}

Received: January 19, 2018

1st Revision: February 28,

2018

Accepted: March 15, 2018

\section{DOI:}

10.14254/jsdtl.2018.3-1.7

\begin{abstract}
This paper typically applied the concept of ranking by inspection using the dwell time of ships in five African ports to evaluate the variations in ship turnaround time and relative efficiency level. This is to identify the active factors that cause port congestion in African ports. The results provided some explanations on the consequences arising from these on notable African logistics and supply chain networks. The findings reveal that the bane of congestion in African ports emanates entirely from either planning, regulation, capacity, efficiency or a combination of these. The regression analysis with IBM SPSS v20 reveals that there is a significant relationship between cargo throughput and other port performance indicators in Nigeria for the study period (2005 - 2014). More so, the t-test reveals that there is a significant relationship between cargo throughput and berth occupancy rate which is significantly indicative of port congestion. This paper therefore recommends that African ports should enhance their regulatory mechanisms, and also improve capacity and efficiency level in order to shoulder the ever increasing challenges of port congestion in years ahead.
\end{abstract}

Keywords: Congestion, dwell time, logistics, ships, ports, cargo.

\subsection{Introduction}

Port Congestion is a scenario associated with delays, queuing and extra time of voyage and dwell time of ships and cargo at the port, which always have unpleasant consequences on Logistics and supply chain. These issues often escalate into extra costs, loss of trade and disruption of trade and transport agreements. In an attempt to pick out the consequences of port congestion on Logistics and supply chain operations in some African ports, this paper examined the common port congestion scenarios, their dimensions and the various factors that cause port congestion in the ports of Lagos, Durban, Mombasa and the catchment ports of the Suez canal in Egypt. The notable indicators include cargo dwell time, operational dwell time, storage dwell time and transactional dwell time defined as the transaction time between the importers / port services and the customs (World Bank, 2011).

Corresponding author: Chinedum Onyemechi

E-mail: c_onyemechi@yahoo.com 
Transporting goods by sea remains the most common way to trade globally, but in Africa cargo spends an abnormally long time in ports before it is moved inland, presenting a serious obstacle to the successful integration of sub-Saharan economies in worldwide trade networks. The port of Durban, however, has managed to buck the trend. World Bank (2012) analyzed performances from six countries and found the average cargo waiting time to be 20 days. It concluded that more than half of the time needed to transport cargo from ports to hinterland cities in landlocked countries in sub-Saharan Africa is wasted because of the time cargoes spend in ports. The African Development Bank (2014) defines dwell time as the time cargoes remain in a terminal's in-transit storage areas while awaiting shipment for export or onward transportation by road or rail to the hinterland as import. Dwell time is one indicator of a port's efficiency because the higher the dwell time, the lower the efficiency and the longer dwell times results to inefficiencies relating to port congestion which can have an adverse effect on economic growth.

\subsection{The Problem}

Port congestion is a problem that affects efficiency levels, performance and productivity of sea ports. Several factors have been identified by most works to be causative to port congestion. These include:

- Excessive demand over supply of port services

- Policy inconsistency of governments

- Poor and obsolete port infrastructure

- Inability of some ports to meet up the technological trends in globalization and manpower problems.

Hence, this work tends to proffer some statistical solutions to these problems in an attempt to bridge the gaps.

\subsection{Objectives}

The main objective of this study is to determine the effects of Port congestion on Logistics and Supply chain with respect to some sub- Saharan African ports. The specific objectives include:

- To evaluate the significant difference in cargo dwell time between the Sub - Saharan African ports.

- To estimate the relationship between cargo throughput, ship waiting time, ship turnaround time and ship call statistics via Nigerian ports.

- To determine extent to which the relationship between cargo throughput and berth occupancy rate indicates port congestion

\subsection{Research Questions}

The following questions would be relevant in the course of this study:

- What is the significant difference in cargo dwell time between the Sub - Saharan African ports?

- What is the relationship between cargo throughput, ship waiting time, ship turnaround time and ship call statistics via Nigerian ports via Nigerian ports?

- To what extent is the relationship between cargo throughput and berth occupancy rate indicative of port congestion?

\subsection{Hypotheses}

The following tentative answers to the questions would be imperative in drawing inferences from the analysis:

- $\mathrm{Ho}_{1}$ : There is no significant difference in cargo dwell time between the Sub - Saharan African ports.

- $\mathrm{Ho}_{2}$ : There is no significant relationship between cargo throughput, ship waiting time, ship turnaround time and ship call statistics via Nigerian ports. 
- $\mathrm{Ho}_{3}$ : The relationship between cargo throughput and berth occupancy rate is not significantly indicative of port congestion.

\subsection{Review of Related Literature}

Most solutions propounded by scholars on effects of port congestion seem to follow the pattern of solutions put forward for sorting port pricing problems. To a large extent, issues surrounding sea port congestions are approached more vividly with solutions that denote wishful thinking. This is in essence of the fact that problems of congestion in ports are multi-dimensional or rather complex. Chang (2009) posits that in an attempt to proffer a workable solution to truck related problems of congestion in a port, He came with a rather inconclusive method of optimization of truck costs to avoid congestion. In this model, Chang listed the following as a way forward. i) Variation in truck volumes in different times of the year needs to be analyzed. ii) Truck waiting cost, gate operating cost and system performance should be evaluated. iii) System utilization should be thoroughly analyzed. iv) Different alternatives for optimization of the gate system must be identified. v) A sensitivity analysis to identify which optimization alternative provides the best gain in efficiency and cost effectiveness must be performed.

\subsection{Effect of Port Congestion on African Trade and Logistics Network}

The National Bureau of Economic Research (2012) asserts that the longer transport times dramatically reduce trade and estimates that each day in transit is worth the value of the goods. Long transit delays also significantly lower the probability that a country will successfully export its goods. Africa's estimated infrastructure deficit of $\$ 48$-billion a year is often singled out as the culprit for hampering trade in and around the continent, but reasons for bottlenecks are far more complex and a lot more challenging to resolve. The World Bank (2012) infers that long dwell times are in the interest of certain players in the system and that dealing with the proximate cause of the problem, such as the apparent lack of berths in African ports, is unlikely to trigger a solution. "Specifically, importers use the ports to store their goods; in Douala (Cameroon) for instance, storage in the port is the cheapest option for up to 22 days (Oyaloye, 2011). The World Bank (2012) posits that Customs brokers, have little incentive to move the goods because they can pass on the costs of delay to the importers. Worse still, when the domestic market is a monopoly, the downstream producer has an incentive to keep the cargo dwell times long as a way of deterring entry of other producers." The evidence in the study shows that discretionary behaviors increase system inefficiencies and raise total logistics costs. "In most ports in sub-Saharan Africa, the interests of controlling agencies, port authorities, private terminal operators, logistics operators (freight forwarders) and large shippers collude at the expense of consumers," the report said. Also the surveys demonstrate that low logistics skills and cash constraints explain why most importers have no incentive to reduce cargo dwell time as, in most cases, doing so would increase their input costs. "Moreover, some terminal operators generate large revenues from storage, and customs brokers do not necessarily fight to reduce dwell time because time inefficiency is charged to the importer and eventually to the consumer."

\subsection{Types of Congestion Prevalent In African Ports}

Major categories of port congestion in Africa are:

- Ship berth congestion, mainly caused by bunching of ships waiting on the port entry routes as a result of other ships said to have occupied the available berth designated or likely to be allocated to the waiting traffic.

- $\quad$ Ship work congestion, mainly caused by delays attributable to lapses in the procedure for work on loading and / or unloading the ship, which could result in stoppages that could elongate the period of time the ship had to remain in port to accomplish the cargo operation task.

- Vehicle Gate congestion, mainly resulting from poor programming of landward access to the port via trucks scheduled arrivals at the port gate. If impediments or programming defaults 
occur, it will instantaneously send queuing signals to trucks coming into or out of the port gate for delivery or evacuation of cargo. This results in port gate congestion.

- Vehicle work congestion, mainly resulting from lapses associated with loading or unloading of vehicle and trucks either due to lack of requisite equipment or due to low efficiency at which vehicle work is delivered.

- Cargo stack congestion, mainly emanating from continuous stay of cargo at the storage area beyond reasonable hours/days or above the maximum capacity of the cargo stacking area.

- Ship entry/exit route congestion, arises mainly when there is any circumstantial blockade on the marine side access routes to the port facility. Such blockade could lead to queuing, bunching and ultimately overstay of ships around the port facility.

\subsection{Causative Factors of Congestion in African Ports}

Different factors trigger congestion in ports. However, the type, extent and dimension of causative factors for Port congestion also differ from port to port. In the same way, the implications of these undesirable congestion drivers also vary from port to port. Typical causes of congestion in African ports include amongst others:

- Bad weather that stops ships or cargo operations;

- Accidents that could suddenly damage port equipment or ship entry route; - - Industrial action that entails work stoppage at the port, labor strike or limitation of stevedoring services.

- Sudden increase or peak in trade demand.

- Surge in international trade on certain articles or between certain countries or regions.

- Land side transport congestion that could slow down the evacuation and delivery of cargo out of the port, thereby blocking the discharge of more cargo as storage capacity is exhausted or overstretched.

Other kinds of congestion prevalent in African ports includes: Congestion on the Shipping lane/route that connects ships to the port, Congestion on port entry or access to a particular terminal, Congestion of ships on port equipment or services, Congestion caused by cumbersome registration, licensing or documentation process, Congestion of cargo on the quay apron, Congestion of trucks within port or terminal, Congestion of cargo at storage yards and sheds, Congestion along the landward access route to the port, Congestion associated with internal mobility in port city, Congestion emanating from effects of public holidays and work free days.

\subsection{Studies on Port Congestion in Sub Saharan Africa}

This study essentially dwells on issues, problems, causes and remedies to port congestion in notable African ports of Durban in South Africa, Lagos in Nigeria, Mombasa in Kenya and Port Said of the Suez Canal in Egypt. The key focus is on the conceptual disposition of the ports towards congestion, which basically identifies prevailing factors that could generate congestion in ports. What type and magnitude of congestion in each port was scrutinized to understand the short and long term manifestation parameters of delays associated with each port's operations. There were obviously different causative factors for congestion to occur in the different African ports. But basically, infrastructural deficiency or underdevelopment seems to top the challenge in all the ports. However the consequences that arise from port congestion in each of the ports surveyed seems to vary, just as the measures adopted by each port to deflect congestion occurrence was necessarily different. In relating the phenomena of port congestion in these African ports this study made the following country specific analysis:

\subsubsection{South Africa}

Durban port is considered a good benchmark for sub-Saharan ports. Its average four-day waiting period for import and export cargo is much closer to best practice in East Asia and Europe, which is a three or four day waiting period. South Africa's commercial ports have been placed firmly in the hands of the state through Transnet. With the exception of these ports and Mombassa in Kenya, all other ports surveyed in the study are run by private container terminal operators. World Bank (2011) study in Durban port reveals that sub-Saharan African ports that the onus was on public sector players such as 
customs and the ports authorities to put pressure on the private sector of port users to comply and reduce cargo dwell times. Prohibitive charges for storage, coupled with strict enforcement and the possibility to pre-clear with customs with advantages attached to it and service level agreements binding both parties, are critical tools for the reduction of cargo dwell time. Major stakeholders acknowledge that the introduction of the "punitive storage charge" after day three is probably the most important single factor affecting dwell time at Durban port. This means that, after 72 hours, containers incur heavy storage charges. The result is that storage charges in Durban are almost six times as high as other ports in the country. But investment in infrastructure has certainly also helped the process. At the time when Durban adopted its port liberalization policy, South Africa's trade infrastructure was ageing and had been neglected for many years, and most of the country's ports were not performing well. From 2002, Transnet invested more than $\$ 700$-million in ports over a five-year period, focusing on creating capacity and equipment. An average dwell time for cargo of four days at Durban port has been achieved and maintained since 2006, which is at par with ports in East Asia and Europe.

\subsubsection{Nigeria}

In an effort to ease congestion at the Lagos Port Complex, Nigeria is looking into ways to encourage shippers to use the country's underutilized eastern ports more. The country identified better use of its eastern ports as one of the quickest ways to decongest Lagos, Nigeria's largest container gateway. Lagos is the second-largest manufacturing hub in the country, which is the continent's largest and fastestgrowing economy. Nigeria has currently been adopting policies and strategies that could encourage shippers to use the country's six main eastern ports at Onne, Calabar, Port-Harcourt, Warri, Sapele and Koko. Nigeria being a predominantly import dependent country, particular for manufactured goods and certain raw materials is always susceptible to port congestion and its negative effects. For instance, strike threat by clearing and forwarding agents associations operating in Nigerian seaports may mean more than imagined for the country's economy as a few days of not moving cargoes out of the Lagos seaports can cause the level of congestion that can create unnecessary expenses and costs to the economy. Another implication of port congestion in Lagos ports is the non-accessible commercial city of Apapa in which thousands of man hours are already being lost to traffic gridlock daily. So much has been said about the gridlock at Apapa that has seemingly defied all solutions. Beyond the confusion on the road, the traffic situation is also said to be affecting ships berthing at the Lagos ports. They are reportedly queuing up for days, and in some cases weeks, before being able to berth and discharge their contents. Vessels conveying containers and other general goods were unable to berth due to lack of space at the port to discharge their contents. Similarly, some tanker vessels conveying petrol, aviation fuel and other liquids are sometimes stranded for days or weeks as they cannot discharge their contents to a number of tank farms located in the Apapa area. This is because tankers expected to take fuel from the tank farms are stuck in traffic. At times over 21 vessels were awaiting berth because of the congestion at the ports. A ship berths when it comes into the port to discharge imported materials and load export materials. In this regard, discharged products are taken away from the ports by trucks. Now, if the trucks can't get in, the imports would remain in the port, leaving no room for fresh imports to be discharged. This would cause ships that have already berthed to wait. If the ships on berth do not leave, those arriving cannot berth. So they would keep waiting, all the while burning fuel and having to pay employees on board. When they could have quickly discharged their contents, picked up exports and moved on to their next destination. The same situation applies to the importation of liquid products like fuel. When a ship brings in fuel, there are smaller vessels that convey this product to the tank farms. Now, if the retail tankers cannot get access to the tank farms to offload the products, there would not be any space for the tank farms to accommodate new products. This is affecting everyone negatively. The roads providing access to the Apapa port from Lagos and the hinterland is also pathetic. So many containers were lost because of the bad roads at Apapa. Sometimes about four containers fell off their trucks in a week, which results into loss of goods and in some cases the truck is lost when it gets damaged in the process. At times ships headed for Nigeria might decide to berth at other West African countries to reduce costs as a result of the congestion. Because there could be ships that have already berthed at the ports but cannot discharge their contents because there is no space for containers and there are still more waiting to berth. This is a costly process because these ships pay demurrage in dollars. The more they wait the more demurrage they pay. When this happen, these ships might go to other West African 
ports that are cheaper and more cost effective, where clearance is obtained within 24 hours (Lisa, 2003). The delay is attributable to the deplorable condition of the port access roads, whereby the haulage trucks were unable to access the ports in a day. Because the trucks have to go beyond the damaged portions of the roads between Trinity bus stop and Coconut axis route to access the ports, at times it takes them days to do this. Some businesses have already relocated out of Apapa because of the traffic situation. The President of the National Council of Managing Directors of Licensed Customs Agents in Nigeria once stated that when Ships/Cargo stay for an extended time, they pay more demurrage and this would in turn extend the price of freight. To this effect Nigeria was losing billions of naira everyday with this trend, it has also made Nigerian ports amongst the most expensive in the world. Other congestion phenomena that impacts on Nigerian ports includes:

- Questions about the efficiency of cargo handling equipment at the terminals, which results into ships waiting to get a space to berth in order to discharge cargo at the terminals. The waiting is often necessitated by the presence of other vessels at the berths discharging cargo as well, albeit slowly.

- Numerous public holidays at certain seasons of the year also disrupts port operations to an extent that queuing results into bunching of vessels either waiting to enter or halting operations at berth or even non-evacuation of cargo out of the port.

- Persistent refusal by shipping companies to transfer their containers to off-dock facilities have also been identified as one of the major causes of congestion at the container storage yards in most terminals in Nigerian ports. 4. As a result of the concession of the Nigerian ports and terminals to private operators by the Nigerian government owned port Authority, the system of ship allocation to berths was controlled by the concessionaires, thereby negating the even spread of berth utilization, which causes congestion in highly patronized terminals leaving less competitive operators with idle berths. This situation compounds waiting time, increases delay and add up to loss of revenue on idle berths.

- Cumbersome ship and cargo clearance and documentation process has also exerted a lot of pressure on congestion in Nigerian ports of Lagos. This is as a fall out of the bureaucratic and multi-agency roles played on the process of ship and cargo clearance in the ports. Delays and subsequent congestion in this regard emanates from positioning of containers for scanning, physical examination and the process of release for delivery, which sometimes takes weeks to accomplish.

\subsubsection{Kenya}

Mombassa port is today, East Africa's major port facility serving Kenya and neighboring countries mainly landlocked Uganda, South Sudan, DR Congo, Rwanda and Burundi. The port is strategically located to serve the Logistics and supply chain requirements of this region. However like every busy African port, the Mombassa port too has its own myriad of events, activities and short-comings that often culminates into port congestion. Like what obtains in most ports of the developing world, lack of infrastructure necessary for effective and efficient port connectivity that will provide standard logistics and supply chain operations is often the problem. The road network leading into Mombassa as well as roads connecting the city to the ports is quite in a state of low traffic carriage capacity relative to the traffic volume connecting the port. This causes a build-up of traffic along the route leading to the Mombassa port. The implication of this is that it slows down the vehicular movement into and out of the port. This further slows down the pace at which cargo is carried into or evacuated from the port, thereby causing congestion of trucks at the port gate, particularly waiting to enter and congestion of cargo at the terminal, particularly waiting for trucks to evacuate same. Power failure that could lead to the shutting down of port cargo handling equipment has at many times caused stoppage of work at the Mombassa port. This by implication could create queue of ships and cargo operations at the port is halted. The effect of all these is delays and subsequent build-up of congestion of both ship and cargo at the port. The power outage often cripple the giant ship to shore cranes at the port including operations at the Mombassa container terminal, thereby slowing down port business and causing port congestion. Another problem of congestion faced by the Mombassa port is the prevalence of abandoned import consignments destined to landlocked countries served by the port. Often Uganda bound containers are stocked at the Mombassa port for durations longer than usual. This leads to accumulation of storage and custom rent 
charges on the cargo. Some of these consignments that dwell for upward of ninety (90) days in storage are deemed to have been abandoned and are subjected to auction sales to create space for incoming cargo. Sometimes waivers and concessions had to be granted as a matter of policy measures to clear the cargo out of the port storage facilities. Another in frastructure problem that is adding up to the events leading to congestion in Mombassa port is the non-completion of the $472 \mathrm{~km}$ Mombassa - Nairobi railway project and other standard rail transport network being built by the Kenyan government. These projects are expected to greatly improve the port's logistics infrastructure and enhance the efficiency of the port's supply chain corridors. The high speed trains, which are designed for double stacking of containers on wagons for evacuation or delivery to the port are expected to reduce the influx and associated congestion of trucks along Kenyan highways and towards the port's landward access. The high speed train service will also ease congestion of cargo at the port through faster and more efficient evacuation of cargo.

\subsubsection{The Suez Canal / Port Said}

The 145 years old Suez Canal that leads into Port Said from the red sea is the fastest and shortest shipping route between Europe and Asia. The canal, with a total length of $72 \mathrm{~km}$ (44.74) miles is gradually raising Egypt's international profile by establishing a major shipping and trade hub at Port Said. This new profile has also placed both the Canal and the Port at a vulnerable position that makes it susceptible to congestion. It has also agitated the Egyptian government to think ahead and plan for the expansion of the Suez Canal. Container (liner) ships make up the largest single share of vessels that transit through the Suez Canal. It is therefore apt to accept the fact that containerized consignments has high sensitivity to logistics systems and operations. Such consignments inhibits high negative impacts on disruption of logistics, supply chain and trade deadlines. It is therefore pertinent to stress that any delays or congestion scenario that could emanate from the Suez Canal or its catchment ports will result into a significant disruption in the transit time of merchandise carried by containerships that passes through the Suez Canal to and fro Europe and Asia. The consequences of congestion on the Suez Canal / Port Said on logistics and supply chain between Europe and Asia could best be imagined. Some notable repercussions include:

- Diversion of some Asia/Europe bound containerships towards the Cape of Good Hope and the gulf of Guinea.

- Delay in cargo delivery will mean default in trade agreements entered into by shippers.

- It will disrupt the inventory level of traders and manufacturers either due to non-receipt of cargo delivery or non-evacuation of such cargo set for shipment by carriers hired.

- It could lead to missed sales.

- It could lead to demurrage charges on ship charter.

- It could lead to increased port cost and anchorage bills.

\subsection{Methodology}

This study is concluded after a cursory observation of the various effects and after effects of both time and monetary-cost problems associated with congestion in some notable African ports. In this regard a simple cause and effect analytical methods were employed to deal with the dominant secondary information and perceptions of stakeholders. Data on operational dwell time, transactional dwell time and storage dwell time of Ship and Cargo in the Ports of Durban, Douala, Lagos, Mombassa and Port Said were analyzed based on individual and total average dwell time of each parameter observed. This will provide the link to rank each of the ports according to their performance in time savings, with the ports having least dwell time ranking higher than ports with high dwell times. This analytical tool slightly varies from the commonly used queuing theory model that seeks to consider mainly the arrival and service time of ships and cargo at ports. 


\subsection{Data Presentation and Analysis}

This section presents data on some performance indicators in sub Saharan African Ports, specifically on cargo dwell time, transactional dwell time, operational dwell time and storage dwell time. More so, a time series data is presented on cargo throughput statistics, import and export statistics of Nigerian ports for a 20 year period (1993-2013).

Table 4.1: Comparison of Cargo Dwell Time in Major African Ports

\begin{tabular}{cccccc}
\multirow{2}{*}{ Type of dwell time } & Durban & Mombassa & Douala & Lagos & Port said \\
\cline { 2 - 6 } & No. of days & No. of days & No. of days & No. of days & No. of days \\
\hline Operational & 2 & 5 & 5 & 5 & 1 \\
Transactional & 1 & 3 & 5 & 4 & 1 \\
Storage & 1 & 3 & 9 & $\mathbf{1 6}$ & 3 \\
\hline Total & $\mathbf{4}$ & $\mathbf{1 1}$ & $\mathbf{1 9}$ & $\mathbf{5}$ \\
\hline
\end{tabular}

Source: Extracted from the World Bank study on cargo dwell time in African ports.

Table 4.1 shows cargo dwell time in major African ports of Durban, Mombasa, Douala, Lagos and Port Said. It shows the magnitude of time measured in days and how the different dwell time relates with each other. Table 4.2 shows that the studied African ports can be ranked in the following order:

\section{Table 4.2: Operational Dwell Time in Port}

$\begin{array}{cccc}\text { S.No } & \text { Port } & \begin{array}{c}\text { Duration in } \\ \text { days }\end{array} & \text { Ranking }\end{array}$

\begin{tabular}{|c|c|c|c|c|}
\hline 1. & Port said & 1 & $1^{\text {st }}$ & \\
\hline 2. & Durban & 2 & $2^{\text {nd }}$ & \\
\hline $\begin{array}{l}3 . \\
4 . \\
5 .\end{array}$ & $\begin{array}{l}\text { Douala } \\
\text { Lagos } \\
\text { Mombassa }\end{array}$ & 5 & $3^{\text {rd }}$ & $\begin{array}{l}\text { These ports exhibit low efficiency in cargo } \\
\text { operation relative to Port Said and the Durban } \\
\text { Port. }\end{array}$ \\
\hline
\end{tabular}

Source: Extracted from the World Bank study on cargo dwell time in African ports.

\section{Table 4.3: Transactional Dwell Time in Port}

$\begin{array}{lccc}\text { S.No. Port } & \begin{array}{c}\text { Duration in } \\ \text { days }\end{array} & \text { Ranking } & \text { Remarks }\end{array}$

1. Durban

2. Port said

3. Mombassa

4. Lagos

5.

Douala
In Durban port and Port Said, customers spend barely a day to process port transactions

Source: Extracted from the World Bank study on cargo dwell time in African ports. 
Table 4.4: Storage Dwell Time in Port

\begin{tabular}{|c|c|c|c|c|}
\hline S.No. & Port & $\begin{array}{c}\text { Duration in } \\
\text { days }\end{array}$ & Ranking & Remarks \\
\hline 1. & Durban & 1 & $1^{\text {st }}$ & \\
\hline 2. & Mombassa & 3 & $2^{\text {nd }}$ & $\begin{array}{c}\text { Both the Mombassa port and Port Said have } \\
\text { an average of } 3 \text { days cargo dwell time, twice } \\
\text { and thrice better than the Lagos and Douala } \\
\text { ports respectively }\end{array}$ \\
\hline 4. & Lagos & 7 & $3^{\text {rd }}$ & \\
\hline 5. & Douala & 9 & $4^{\text {th }}$ & \\
\hline
\end{tabular}

Source: Extracted from the World Bank study on cargo dwell time in African ports.

\subsection{Results and Findings}

Port congestion in Africa is an inevitable seasonal occurrence that is largely associated with improper planning, inadequate equipment or dearth of ancillary infrastructure that could support the transport and logistics network requirements of the African ports. The manifestation of congestion in most African ports is attributable to either capacity constraints or procedural delays emanating from weak planning or docile regulatory mechanisms. But generally, stages of development attributable to the level of investment on port facilities and superstructure presents the most cogent reason for the perennial congestion in most African ports. From Lagos to Mombassa and from Durban to Port Said at the Suez, the phenomena of congestion has impacted negatively and continuously for that matter on efficiency, cost effectiveness and revenue stream of affected ports.

A survey undertaken by this paper actually accepts that amongst all the ports surveyed, which included Durban, Mombassa, Douala, Lagos and Port Said, the Durban port has carried the day with the least cargo dwell time amongst all the other ports studied.

This is achieved through the disincentive of only three days allowed as free dwell time of cargo at the Durban port compared to seven (7) days in Lagos and up to nine (9) days of dwell time in Douala port, which is more like offering an incentive to misuse port facilities for storage.

It follows from the analysis that operational dwell time is least in Port Said, followed by Durban with two (2) days and it takes up to an average of five (5) days in Lagos, Douala and Mombassa to complete operational transactions in the ports.

\section{Table 4.5: Some Port Performance Indicators in Nigeria}

\begin{tabular}{cccccc} 
Year & Cargo Throughput (mt) & Waiting time & $\begin{array}{c}\text { Turnaround } \\
\text { time }\end{array}$ & $\begin{array}{c}\text { Berth } \\
\text { occupancy } \\
\text { (\%) }\end{array}$ & $\begin{array}{c}\text { NO. OF } \\
\text { VESSELS }\end{array}$ \\
\hline 2005 & $22,232,936$ & 0.47 & 6.17 & 27.76 & 3,123 \\
2006 & $28,932,880$ & 0.46 & 6.34 & 36.68 & 3,333 \\
2007 & $35,940,692$ & 0.47 & 6.71 & 36.73 & 3,745 \\
2008 & $36,987,241$ & 0.39 & 7.31 & 41.39 & 3,500 \\
2009 & $39,765,945$ & 0.36 & 6.31 & 47.09 & 3,661 \\
2010 & $40,816,947$ & 0.34 & 7.01 & 44.76 & 3,606 \\
2011 & $44,952,073$ & 1.27 & 7.91 & 51.78 & 3,692 \\
2012 & $49,173,324$ & 3.99 & 11.34 & 56.58 & 3,689 \\
2013 & $54,641,048$ & 2.17 & 7.89 & 52.75 & 4,646 \\
2014 & $65,192,919$ & 1.44 & 6.44 & 50.93 & 4,477 \\
\hline
\end{tabular}

Sources: Nigeria Ports Authority (NPA) Abstract of Ports Statistics 
Transaction wise, the dwell time is least in Durban and Port Said, as port transaction can be completed within a day. Whereas it takes up to 3, 4 and 5 days respectively for Mombassa, Lagos and Douala ports.

The Durban port's outlook is the best in terms of storage system management. The cargo dwell time in the Durban port is merely an average of a day per cargo storage dwell time. This situation is remarkably different from what obtains in the other ports that exhibits cargo storage dwell time of between three (3) to nine (9) days.

Table 4.5 displays a time series data of 10 years comprising cargo throughput statistics of Nigerian ports, number of vessels that called at the ports, the average waiting time of the vessels in days, ship turnaround time in days and berth occupancy rate. It is observed that c]argo throughput rose over time, recording highest values between 2010 and 2014.vessel [waiting time increased from 2011, declined in 2013 and rose again in 2014 while ship turnaround time kept fluctuating over time from 2005 to 2014, unlike the berth occupancy rate that increased over the years. This implies that the post reform era has some impact on the logistics and supply chain of Nigerian ports. The berth occupancy rate justifies the increased number of vessels call and cargo throughput passing through the ports.

\section{Table 4.6 Correlations}

\begin{tabular}{ccccccc}
\hline & & $\mathbf{y}$ & $\mathbf{x 1}$ & $\mathbf{x 2}$ & $\mathbf{x 3}$ & $\mathbf{x 4}$ \\
\hline & $\mathrm{Y}$ & 1.000 & .559 & .344 & .848 & .894 \\
Pearson Correlation & $\mathrm{x} 1$ & .559 & 1.000 & .904 & .711 & .409 \\
& $\mathrm{x} 2$ & .344 & .904 & 1.000 & .649 & .132 \\
& $\mathrm{x} 3$ & .848 & .711 & .649 & 1.000 & .662 \\
& $\mathrm{x} 4$ & .894 & .409 & .132 & .662 & 1.000 \\
\hline \multirow{3}{*}{ Sig. (1-tailed) } & $\mathrm{Y}$ &. & .047 & .165 & .001 & .000 \\
& $\mathrm{x} 1$ & .047 &. & .000 & .011 & .120 \\
& $\mathrm{x} 2$ & .165 & .000 &. & .021 & .358 \\
& $\mathrm{x} 3$ & .001 & .011 & .021 &. & .018 \\
& $\mathrm{x} 4$ & .000 & .120 & .358 & .018 &. \\
\hline & $\mathrm{Y}$ & 10 & 10 & 10 & 10 & 10 \\
& $\mathrm{x} 1$ & 10 & 10 & 10 & 10 & 10 \\
& $\mathrm{x} 2$ & 10 & 10 & 10 & 10 & 10 \\
& $\mathrm{x} 3$ & 10 & 10 & 10 & 10 & 10 \\
& $\mathrm{x} 4$ & 10 & 10 & 10 & 10 & 10 \\
\hline
\end{tabular}

Source: IBM SPSS 20

Table 4.6 shows that the variables are positively correlated with the Pearson correlation. This implies that cargo throughput has positive correlation with ship waiting time, ship turnaround time, berth occupancy rate as well as with the number of ships that called to the ports and vice versa. This is supported by their respective values as indicated by table 4.6 .

Table 4.7: Model Summary b

\begin{tabular}{|c|c|c|c|c|c|c|c|c|c|c|}
\hline \multirow[b]{2}{*}{ Model } & \multirow[b]{2}{*}{$\mathrm{R}$} & \multirow[b]{2}{*}{$\begin{array}{c}\mathrm{R} \\
\text { Square }\end{array}$} & \multirow[b]{2}{*}{$\begin{array}{c}\text { Adjusted } \\
\text { R } \\
\text { Square }\end{array}$} & \multirow[b]{2}{*}{$\begin{array}{l}\text { Std. Error of the } \\
\text { Estimate }\end{array}$} & \multicolumn{5}{|c|}{ Change Statistics } & \multirow[b]{2}{*}{$\begin{array}{l}\text { Durbin- } \\
\text { Watson }\end{array}$} \\
\hline & & & & & $\begin{array}{c}\text { R } \\
\text { Square } \\
\text { Change }\end{array}$ & $\mathrm{F} \mathrm{Cl}$ & df1 & $\mathrm{df} 2$ & $\begin{array}{l}\text { Sig. F } \\
\text { Change }\end{array}$ & \\
\hline 1 & $.961^{\mathrm{a}}$ & 923 & .862 & 4608172.53230 & .923 & 15.084 & 4 & 5 & .005 & 2.759 \\
\hline
\end{tabular}

a. Predictors: (Constant), $\mathrm{x} 4, \mathrm{x} 2, \mathrm{x} 3, \mathrm{x} 1$

b. Dependent Variable: $y$

Table 4.7 shows an R square value of 0.923 , which implies that $92.3 \%$ of the independent variables (ship waiting time, ship turnaround time, berth occupancy rate and ship call statistics) are explained in the dependent (cargo throughput) variable. 


\begin{tabular}{ccccccc}
\multicolumn{2}{l}{ Table 4.8: ANOVA } \\
\multicolumn{2}{c}{ Model $^{\mathbf{a}}$} & Sum of Squares & df & Mean Square & F & Sig. \\
\hline \multirow{2}{*}{1} & Regression & 1281236606461216.000 & 4 & 320309151615304.000 & 15.084 & $.005^{\text {b }}$ \\
& Residual & 106176270437226.380 & 5 & 21235254087445.273 & & \\
\hline & Total & 1387412876898442.500 & 9 & & & \\
\hline
\end{tabular}

a. Dependent Variable: y

b. Predictors: (Constant), x4, x2, x3, x1

Table 4.8 shows the analysis of Variance for the relationship between cargo throughput, ship waiting time, ship turnaround time, berth occupancy rate and ship call statistics. This shows the variation of the values of the variables around their mean. It further, reveals an F- statistics of 15.084. This is a test of significance for ANOVA. This value is greater than the critical value and hence we reject the null hypothesis that there is no significant relationship between cargo throughput, ship waiting time, ship turnaround time, berth occupancy rate and ship call statistics.

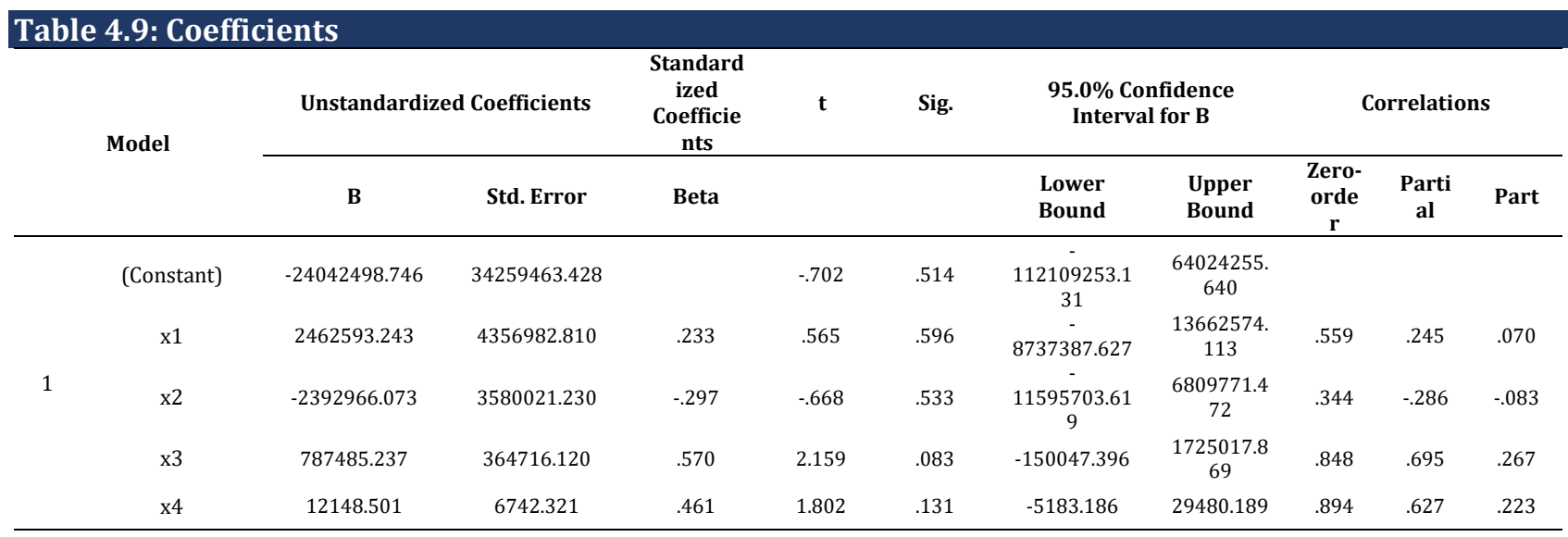

a. Dependent Variable: y

- Table 4.8 shows the relationship between the variables. The t- statistics gives a value of 0.565 , $0.668,2.159$ and 1.802 ship waiting time, ship turnaround time, berth occupancy rate and ship call statistics respectively. The t- test values for ship waiting time, ship turnaround time are less than 2 but greater than -2, while berth occupancy rate has a value of 2.159 being statistically significant in the model; we therefore reject the null hypothesis that The relationship between cargo throughput and berth occupancy rate is not significantly indicative of port congestion.

\subsection{Conclusion}

It can be deduced from the foregoing analysis that the Durban and Port Said facilities are the most congestion resistant ports in Africa, largely due to the operational dispensation of the ports and the solid strategies adopted by the ports in managing cargo storage systems. Reducing regulated cargo dwell time in ports and the time frame within which transactions are concluded in ports also provides effective control measures against common causes of port congestion. And as the causative factors for port congestion in each of these African ports are largely unique to the ports, each port should adopt the most effective solution mechanisms for tackling unique congestion inducing practices. Most of all the issue of increasing capacity, regulations and investment in basic infrastructure and modern equipment will go a long way in easing port congestion in African Ports.

It could be deduced that cargo throughput and berth occupancy rate are significantly related which implies that they with other factors are indices of port congestion when the demand for ports services exceeds the supply. It may as well indicate that the other variables used are not significant factors affecting port congestion in Nigeria. 


\subsection{Recommendations}

For African ports to fall in line with the requirements of global logistics and supply chain network, concerted efforts must be made to eliminate all port practices that induce congestion and to invest more on facilities and platforms that can enhance efficiency in optimizing operational, transactional and storage systems in the ports. In this regard, this paper posits the following recommendation to achieve less congestion problems in African ports.

1. At port entry channels level, African ports should adopt good strategies to manage and maintain all port entry channels and its vicinity by deploying adequate and accurate programming of ships' arrival, anchorage and departure from the ports to avoid queuing and bunching of ships waiting around, particularly in Nigeria.

2. The widths of channels leading into ports should be expanded and continuously dredged to ease the entry and exit of ships calling at the ports, particularly in Lagos, Durban and the Suez ports.

3. Daily average arrival and departure statistics of ship call in all the ports need to be maintained to enhance programming of ship arrival and departure in line with port capacity.

4. Berth specialization should be upgraded to enhance operational efficiency of terminals and to optimize berth occupancy.

5. Invest more on terminal cargo handling gears for the purpose of improving berth work efficiency and reduce turn-round time of vessels at port. throughput.

6. Improve average speed in cargo transfer to reduce dwell time and enhance ports' cargo

7. At storage yards, sheds and warehouses, cargo storage capacity needs to be upgraded and regulations modified to reduce cargo dwell time through punitive measure and persuasions on shippers to take delivery in good time. 8. The ports in Lagos, Mombassa and Douala are in dire need of rehabilitation and upgrade of all landward access mediums to the ports, such as road networks, functional rail services and good traffic management practices for vehicular movement into and around the port area.

\section{Appendix A. Supplementary material}

Supplementary data associated with this article can be found, in the online version, at https://jsdtl.sciview.net

\section{Funding}

The authors received no direct funding for this research.

\section{Citation information}

Nze, I. C., \& Onyemechi, C. (2018). Port congestion determinants and impacts on logistics and supply chain network of five African ports. Journal of Sustainable Development of Transport and Logistics, 3(1), 70-82. doi:10.14254/jsdtl.2018.3-1.7

\section{References}

African Development Bank. (2014). Cargo Dwell Time in African Ports. The African Development Bank.

Chang, Q. G. (2009). Analysis of Marine Container Terminal Gate Congestion, Truck Waiting Cost and System Optimization. New Jersey Institute of Technology.

Jannson, J. O., \&b Shnearson, D. (2009). In Kevin C., Wayne K.. Port Economics. Taylor \& Francis. London.

Lisa, S. (2013). Port congestion in Nigeria. The Mail \& Guardian, 14 June.

Oyatoye, E. O., Adebiyi, S. O., Okoyee, J. C., \& Amole, B. B. (2011). Application of Queueing theory to port congestion problem in Nigeria. European Journal of Business and Management, 3(8). 
Samson, E. (2014). Congestion and Port Development: Issues and Challenges. Leadership Newspaper, Nov 7.

UNCTAD - Port Performance Indicators - TB/B/C.4/131/Supp.1/Rev 1. Retrieved from www.freshfruitportal.com World Bank. (2011). Cargo Dwell Time in Durban: Lessons for Sub-Saharan African Ports. The World Bank Group. World Bank. (2012). Why does cargo spend weeks in sub-Saharan African ports? The World Bank.

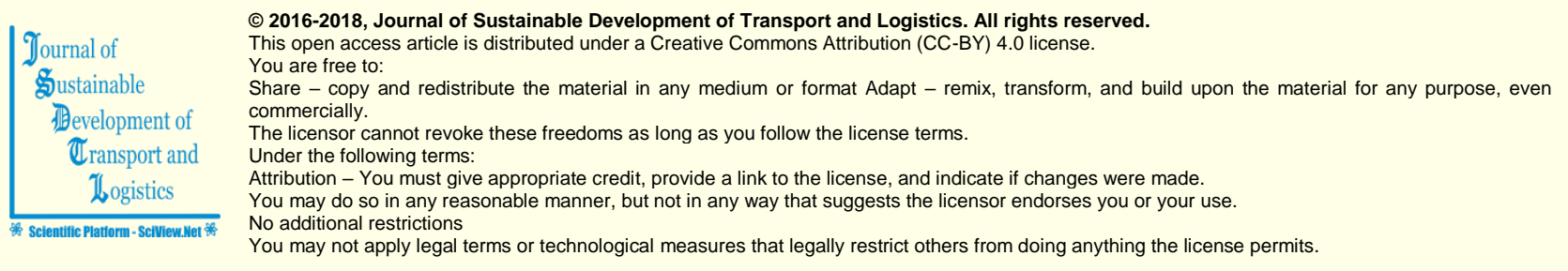

Journal of Sustainable Development of Transport and Logistics (ISSN: 2520-2979) is published by Scientific Publishing House "CSR", Poland, EU and Scientific Publishing House "SciView", Poland, EU

Publishing with JSDTL ensures:

- Immediate, universal access to your article on publication

- High visibility and discoverability via the JSDTL website

- Rapid publication

- Guaranteed legacy preservation of your article

- Discounts and waivers for authors in developing regions

Submit your manuscript to a JSDTL at https://jsdtl.sciview.net/ or submit.jsdt|@sciview.net 